\title{
Seroprevalence of Hepatitis $B$ virus and Hepatitis $C$ virus in healthcare workers - AIMS, B G Nagara
}

\author{
Vijaya Doddaiah, Katta Janakiram, Sathish Javagal \\ Department of Microbiology, Adichunchanagiri Institute of Medical Sciences, B.G.Nagara 571448, Karnataka, India
}

Email address:

vijayadanand@rediffmail.com(V. Doddaiah)

\section{To cite this article:}

Vijaya Doddaiah, Katta Janakiram, Sathish Javagal. Seroprevalence of Hepatitis B Virus and Hepatitis C Virus in Healthcare Workers AIMS, B G Nagara. American Journal of Life Sciences. Vol. 1, No. 4, 2013, pp. 145-149. doi: 10.11648/j.ajls.20130104.11

\begin{abstract}
Healthcare workers have an elevated risk of acquiring and transmitting parental infections. The purpose of this study was to determine the seroprevalence of HBV and HCV among the health care workers. One hundred and sixty eight HCWs (doctors-6, nurses-38, technicians-10, ward attenders-91, nursing students-23) were screened for HBsAg. These HCWs were not vaccinated against hepatitis B virus infection. Among them, two (1.19\%) were positive for HBsAg. The positive persons were ward attenders ( 1 male, 1 female) who handle hospital waste. Four hundred and five HCWs (doctors88 , nurses-155, technicians-30, ward attenders-107, nursing student-25) were screened for HCV antibodies. None of the HCWs were positive for HCV antibodies. Health education, prophylaxis by vaccination, universal precautions and proper hospital waste management play a major role in the prevention of HBV and HCV infection. This is the first study undertaken from this hospital on the prevalence of HBV and HCV infection among HCWs after of 27 years establishment of the hospital.
\end{abstract}

Keywords: HBV, HCV, Health Care Workers

\section{Introduction}

Healthcare workers (HCWs) are those (e.g., doctors, nurses, technicians, students, ward boys/ aaya and sweepers) who come in contact with patients /with blood / other body fluids from patients in a healthcare set up. Hepatitis B and $\mathrm{C}$ are two hepatotropic blood borne viruses that are important cause of liver related mortality and morbidity. They have similar modes of transmission by parenteral, sexual and perinatal modes [1]. Hepatitis B virus (HBV) is the greatest threat of infection to HCWs. The risk of contracting $\mathrm{HBV}$ by healthcare personnel is four times greater than that of the general adult population, among those who do not work in healthcare institutions [2]. Hepatitis $\mathrm{C}(\mathrm{HCV})$ is an emerging infection in India and an important pathogen causing liver disease in India.Healthcare workers have a high risk of occupational exposure to many blood borne diseases including HIV, Hepatitis B, and Hepatitis C viral infections. Of these Hepatitis B is not only the most transmissible infection, but also only one that is preventable by vaccination [3].

Immunization against $\mathrm{HBV}$ is not mandatory in most of the hospitals in India prior to recruitment .The present study was designed to determine the seroprevalence of
Hepatitis $\mathrm{B}$ virus and Hepatitis $\mathrm{C}$ virus among healthcare workers in a rural hospital attached to Medical School at B.G.Nagara, Karnataka. This is the first study undertaken from this hospital on the prevalence of $\mathrm{HBV}$ and $\mathrm{HCV}$ infection among HCWs after of 27 years establishment of the hospital.

\section{Material and Methods}

The study was conducted for a period of one year from January - December 2012. This is a prospective study comprising of 405 HCWs. Age, sex, occupation, working place, and H/o blood transfusion /jaundice was recorded for all participants. Participation in the study was voluntary and strict confidentiality was ensured. Ethical clearance for the study was obtained from the institution. After an informed oral consent $5 \mathrm{ml}$ of blood sample was collected and serum separated was stored at $-20^{\circ} \mathrm{C}$ for further testing.

Detection of Hepatitis B virus infection: A total of 168 non- vaccinated HCWs (doctors, nurses, technicians, ward attenders and nursing students) formed the study group. As HBsAg is the most reliable and universal marker of HBV infection, serum was screened for HBsAg using Hepa Card (Diagnostic Enterprises, H.P.) and ELISA (J. Mitra \& Co. 
Pvt Ltd, New Delhi).

Detection of Hepatitis C virus infection: A total 405 $\mathrm{HCWs}$ were screened for $\mathrm{HCV}$ infection using $\mathrm{HCV}$ tridot (Diagnostic Enterprises, H.P.) and ELISA (HCV microlisa, J. Mitra \& Co. Pvt Ltd, New Delhi) for HCV antibodies.

\section{Results}

Four hundred and five HCWs including doctors $(21.72 \%)$, nurses $(38.27 \%$, ) technicians $(7.4 \%)$, ward attenders $(26.41 \%)$ and nursing students $(6.17 \%)$ formed the study group. 172 were male and 233 were female. The age range of the study group was 19-60 years (mean age of $31.82 \pm 7.4$ years). No previous H/o blood transfusion, hospitalization or suffered from jaundice prior to testing. All participants in the institution had service of 5-25 years except nursing students. Among 405 HCWs, 237 (58.52\%) were vaccinated and $168(41.48 \%)$ were non- vaccinated against $\mathrm{HBV}$.

A total of 168 (male 82, female 86) non -vaccinated HCWs were screened for HBV infection. Out of 168, two $(1.19 \%)$ were positive for HBsAg. Both (male and female each) were ward attenders by occupation. Sex distribution and HBsAg positivity in relation to occupation is shown in table 1. Seromarkers and LFT findings of HBsAg positive HCWs are given in table 2.

A total of $405 \mathrm{HCWs}$ (male 172, female 233) studied for $\mathrm{HCV}$ infection. None of them were positive for $\mathrm{HCV}$ antibodies. The demographic data of health care workers screened for Hepatitis $\mathrm{C}$ virus infection is given in table 3 .

\section{Discussion}

HBV has been found to infect about 350 million people globally [4]. Hepatitis B and C are global problems mostly in the developing countries. Hepatitis B virus is one of the major public health problems globally and is the tenth leading cause of death. In India, HBsAg prevalence among the general population ranges from $2-8 \%$, which places India in an intermediate HBV endemicity zone and India with 50 million cases, is also second largest global pool of chronic HBV infections [5, 6]. Among HCWs seroprevalence is 2 to 4 times larger than that of general population [3].

The present study shows prevalence of HBV $1.19 \%$ in HCWs, which is compared with other studies in table 4 . Distribution of HBsAg positivity is not associated with age or gender which is in correlation with the study of Vipul MK [7].

HBV positive HCWs (one male, 52 years and one female, 45 years) in the present study were ward attenders by profession and were handling hospital waste since twenty years. They were not tested for $\mathrm{HBV} / \mathrm{HCV}$ infection previously. The source of infection for these persons could be blood or blood products present in the hospital waste, as HBV survive in dried blood, at room temperature, on environmental surfaces for a long time. Positive HCWs were further studied for seromarkers like $\mathrm{HBeAg}, \mathrm{HBsAb}$ and liver function tests (LFT) to assess the infectivity, prognosis and to know the involvement of liver as shown in table 2 .

In the present study nurses and technicians were negative for HBV infection where as others have reported positivity among this groups [8,9]. Risk of HBV infection is primarily related to the degree of contact with blood in the work place and also to the hepatitis B and $\mathrm{HBe} \mathrm{Ag}$ status of source person.

There are about 130 million persons having $\mathrm{HCV}$ infection over the world. Its prevalence varies from region to region. The highest prevalence $(15-20 \%)$ has been found in Egypt while UK has the lowest prevalence (0.01-0.1\%) [10].

A total of $405 \mathrm{HCWs}$ studied for $\mathrm{HCV}$ infection, all were negative for $\mathrm{HCV}$ antibodies, could be due to low infectivity of HCV. This has been compared with the other studies in the table 4.

In the present study there was no mixed infection of HBV and HCV where as Sarwar J et al., have reported the mixed infection.

Table 5 shows the seropositivity of HBV and HCV among HCW as reported by other workers in relation to occupation in percentage.

\section{Conclusion}

HCWs play an important role in health care set up and protection of HCWs is of utmost importance to the institution. At the time of recruitment each person has to be screened for HBV, HCV and HIV infections. Persons who are not vaccinated for HBV has to be vaccinated which is not followed in most of the hospitals in India. Health care workers has to be educated regarding universal precautions, proper hospital waste management, precaution, hazards and preventive measures etc. Yearly screening of the workers should be done in order to detect infection early and take preventive and therapeutic measures.

\section{Acknowledgement}

The study was supported by Sri Adichunchanagiri Shikshana Trust, B G Nagara. Authors are grateful to president, Poojya Guru Sri Nirmalananadanatha Swamiji, Trustee Mr. D. Devaraj and Advisor Dr. Sunil M. Our special thanks to Dr. S. Kanti, Director and Dr. M.G. Shivaramu, Principal, AIMS, B G Nagara for allowing us to conduct this study. We are grateful to the health staff who participated in this study. 
Table 1. Sex distribution and HBsAg positivity in relation to occupation

\begin{tabular}{llllll}
\hline Occupation & Sex & & & & \\
& Male & & & Female & \\
& Negative & Positive & Negative & Positive & Total \\
Doctors & 03 & 00 & 03 & 00 & (No:06) \\
Nurses & 13 & 00 & 25 & 00 & (No:38) \\
Technicians & 06 & 00 & 04 & 00 & (No:10) \\
Ward attenders & 51 & 01 & 38 & 01 & $($ No: $: 91)$ \\
Nursing students & 08 & 00 & 15 & 00 & (No:23) \\
Total & 81 & 01 & 85 & 01 & (No:168) \\
\hline
\end{tabular}

Table 2. Seromarkers and LFT and findings of HBsAg Positive HCWs

\begin{tabular}{|c|c|c|}
\hline Investigation & Case1 (Female) & Case2 ( Male) \\
\hline \multicolumn{3}{|l|}{ SEROMARKERS } \\
\hline HBs Ag & Positive & Positive \\
\hline $\mathrm{HBeAg}$ & Negative & Negative \\
\hline $\mathrm{HBsAb}$ & $<10 \mathrm{mIU} / \mathrm{ml}$ & $<10 \mathrm{mIU} / \mathrm{ml}$ \\
\hline \multicolumn{3}{|l|}{ Liver function tests } \\
\hline \multicolumn{3}{|l|}{ (Reference value) } \\
\hline Total bilirubin (0.2-1.2) & 0.56 & 0.53 \\
\hline Direct bilirubin (0.02-0.4) & 0.28 & 0.26 \\
\hline Indirect bilirubin & 0.28 & 0.27 \\
\hline Total protein $(6.2-8.0)$ & 8.0 & 8.0 \\
\hline Albumin $(3.2-5.2)$ & 3.0 & 3.0 \\
\hline \multicolumn{3}{|l|}{ Albumin to Globulin ratio } \\
\hline$(2.5-3.8)$ & 5.0 & 5.0 \\
\hline Alkaline Phosphatase (70) & 18 & 93 \\
\hline $\operatorname{AST}(<31)$ & 24 & 38 \\
\hline $\operatorname{ALT}(<31)$ & 43 & 55 \\
\hline
\end{tabular}

Table 3. Showing the demographic data healthcare workers studied for Hepatitis C virus infection / demographic profile of study population

\begin{tabular}{llll}
\hline Occupation & Sex & & Total \\
& Male & Female & \\
& & & 88 \\
\hline Doctors & 50 & 38 & 155 \\
Nurses & 25 & 130 & 30 \\
Technicians & 26 & 04 & 107 \\
Ward attenders & 60 & 47 & 25 \\
Nursing students & 11 & 14 & \\
\hline
\end{tabular}


Table 4. Showing the prevalence of Hepatitis B virus and Hepatitis C virus infections among health care workers as reported by various workers

\begin{tabular}{|c|c|c|}
\hline Authors & HBV (\%) & HCV (\%) \\
\hline Vijaya D et al., 2012 & 1.19 & 00 \\
\hline Vipul MK et al., $2012^{7}$ & 2.4 & -- \\
\hline Shoaei P et al., $2012^{11}$ & -- & 00 \\
\hline Attaullah S et al., $2011^{12}$ & 2.18 & -- \\
\hline Ziraba AK et al., $2010^{13}$ & 8.1 & -- \\
\hline Singh G et al., $2010^{9}$ & 0.4 & -- \\
\hline Sukriti et al., $2008^{14}$ & 1.0 & -- \\
\hline Sarwar J et al., $2008^{8}$ & 30 & 30 \\
\hline Kondili LA et al., $2007^{15}$ & 8.1 & 0.6 \\
\hline Alam S et al., $2007^{16}$ & -- & 1.4 \\
\hline Nidhi J et al., $2006^{17}$ & -- & 4.0 \\
\hline Luiz AS et al., $2005^{18}$ & 0.8 & -- \\
\hline Petrosillo $\mathrm{N}$ et al., $2004^{19}$ & 23.3 & 2.0 \\
\hline Duseja et al., $2000^{20}$ & 1.7 & 0.87 \\
\hline Daw MA et al., $2000^{21}$ & 31 & -- \\
\hline Thorburn D et al., $2002^{22}$ & -- & 0.28 \\
\hline Arankalle VA et al., $1995^{23}$ & -- & 4.0 \\
\hline
\end{tabular}

Table 5. Seropositivity of HBV and HCV among HCW as reported by other workers in relation to occupation in percentage

\begin{tabular}{|c|c|c|c|c|c|c|}
\hline Occupation & Doctors & Nurses & Technicians & Ward attenders & Dental staff & Nursing students \\
\hline \multicolumn{7}{|l|}{ HBV } \\
\hline Vijaya D et al., 2012 & 00 & 00 & 00 & 1.2 & -- & 00 \\
\hline Vipul MK et al., $2012^{7}$ & 00 & 1.7 & 4.1 & 1.9 & -- & -- \\
\hline Attaullah S et al., $2011^{12}$ & 00 & 44.0 & 33.4 & 22.0 & -- & -- \\
\hline Singh $\mathrm{G}$ et al., $2010^{9}$ & -- & -- & - & - & -- & 0.4 \\
\hline Sarwar J et al., $2008^{8}$ & 00 & 30.0 & 10.0 & 20.0 & -- & -- \\
\hline \multicolumn{7}{|l|}{$\mathrm{HCV}$} \\
\hline Vijaya D et al., 2012 & 00 & 00 & 00 & 00 & -- & 00 \\
\hline Andrea Marconi $2010^{24}$ & 5.0 & 3.0 & 1.5 & -- & -- & -- \\
\hline Alam S et al., $2007^{16}$ & 0.56 & 0.84 & -- & -- & -- & - \\
\hline Thorburn et al $2000^{22}$ & $0.23 / 0.32$ & 0.23 & -- & -- & 1.7 & -- \\
\hline Puro V et al $1995^{25}$ & $0.9 / 1.4$ & 1.9 & 0.8 & 1.3 & -- & - \\
\hline
\end{tabular}

\section{References}

[1] Vinod S, Wal N, Venkatesh V, Tandon R, Singh M, Singh R. Seropositivity rates for Hepatitis $B$ and $C$ viruses in a tertiary care centre of Northern India. Webmedcentral VIROLOGY 2010; 1(11):WMC001197.

[2] Byrne EB. Viral hepatitis: on occupational hazard of medical personnel. Experience of the Yale-New Haven Hospital, 1952-1965.JAMA 1996; 195: 362-4.

[3] Singhal V, Bora D, Singh S. Hepatitis B in health care workers: Indian scenario. J Lab Physicians 2009:1:41-48.

[4] Lavanchy D. Hepatitis B virus epidemiology, disease burden, treatment, and current and emerging prevention and control measures. J Viral Hepat 2004; 11: 97-107.

[5] WHO. Hepatitis B: WHO / CDS / CSR / LYO / 2002.2: Hepatitis B. Available at http:// www.who.int /csr /disease / hepatitis / whocdscsrlyo 20022 /en / print.html 2009.

[6] Gupta S, Gupta R, Joshi YK, Singh S. Role of horizontal transmission in hepatitis B virus spread among household contacts in north India. Intervirology 2008; 51:7-13.
[7] Vipul MK, Rubee CT, Deepak NP, Chirag PP. Prevalence of hepatitis B virus infection in health care workers of a tertiary care hospital. N J Med Res 2012; 2(2):176-8.

[8] Sarwar J, Gul N, Idris M, Anis-ur-Rehman, Farid J, Adeel MY. Seroprevalence of hepatitis B and Hepatitis C in health care workers in Abbottabad. J Ayub Med Coll Abbottabad 2008; 20(3):27-29.

[9] Singh G, Singh Mp, Walia I, Sarin C, Ratho RK. Screening for hepatitis $\mathrm{B}$ and $\mathrm{C}$ viral markers among nursing students in a tertiary care hospital. Indian Journal of Med Microbiol 2010; 28(1):78-79.

[10] Perz JF, Armstrong GL, Farrington LA, Hutin YJ, Bell BP. The contributions of hepatitis $B$ virus and hepatitis $C$ virus infections to cirrhosis and primary liver cancer worldwide. J Hepatol 2006;45:529-38.

[11] Shoaei P, Lotfi N, Hassannejad R., Yaran M, Ataei B , Kassaian N, et al. Seroprevalence of hepatitis C infection among laboratory workers in Isfahan, Iran. Int J Prev Med, 2012; special issue, S146-9.

[12] Attaullah S, Khan S, Naseemullah, Ayaz S, Khan SN, Ali I, et al. Prevalence of HBV and HBV vaccination coverage in health care workers of tertiary hospitals of Peshawar, Pakistan. Virology Journal 2011; 8:275. 
[13] Ziraba AK, Bwogi J, Namale A, Wainaina WC, Kizza HM. Sero-prevalence and risk factors for hepatitis B virus infection among health care workers in a tertiary hospital in Uganda. BMC Infect Dis 2010; 10:191.

[14] Sukriti, Patil NT, Sethi A, Agarwal K, Agarwal K, Kumar GT, et al. Low levels of awareness, vaccine coverage and the need for boosters among healthcare workers in tertiary care hospitals in India. J Gastroenterol Hepatol 2008; 23:1710-5.

[15] Kondili LA, Ulqinaku D, Hajdini M, Basho M, Chionne P, Madonna E, et al. Hepatitis B virus infection in Health care workers in Albania: a country still highly endemic for HBV infection. Infection 2007; 35(2):94-7.

[16] Alam S, Ahmad N, Khan M, Mustafa G, AL Mamun A, Mashud G. Seroprevalence of Hepatitis C virus infection among health care workers. J Bangladesh College of Physicians and Surgeons 2007; 25(3): 126-129

[17] Nidhi J, Mohit J, Nishat J, Kar P. Seroprevalence of hepatitis $\mathrm{C}$ virus (HCV) in health care workers of a tertiary care centre in New Delhi. Indian J Med Res 2006; 123:179180 .

[18] Luiz AS, Ciorlia, Dirce MTZ. Hepatitis B in health care workers: prevalence, vaccination and relation to occupational factors. Brazilian J infect Dis 2005; 9(5):384389

[19] Petrosillo N, Puro V, Ippolito G, Di Nardo V, Albertoni F , Chiaretti B et al. Hepatitis B virus, hepatitis $\mathrm{C}$ virus and human immunodeficiency virus infection in health care workers : a multiple regression analysis of risk factors. Doi: 10.1016/0195-6701(95)90262-7.

[20] Duseja A, Arora L, Masih B, Singh H, Gupta A, Behera D et al. Hepatitis $B$ and $C$ virus - prevalence and prevention in health care workers. Trop Gastroenterol 2002; 23(3):125-6.

[21] Daw MA, Siala IM, Warfalli MM, Muftah MI. Seroepidemiology of hepatitis B virus markers among hospital health care workers. Analysis of certain potential risk factors. Saudi Med J 2000 ; 21(12):1157-60.

[22] Thorburn D, Dundas D, McCruden EAB, Cameron SO, Goldberg DJ, Symington IS et al. A study of hepatitis C prevalence in health care workers in the west of Scotland. Gut 2001; 48:116-120.

[23] Arankalle VA, Chadha MS, Jha J, Amrapurkar DN, Banerjee $\mathrm{K}$. prevalence of anti-HCV antibodies in western India. Indian J Med Res1995; 101:91-93.

[24] Andrea M, Saverio C, Renato T, Massimo L, Ferdinando N, Demetrios A et al. Prevalence of hepatitis $\mathrm{C}$ virus infection among health care workers : A 10 year survey. Molecular Medicine Reports 2010; 3: 561-564.

[25] Puro V, Petrosillo N, Ippolito G, Stella MA, Boumis E, Rava $\mathrm{L}$ et al. Occupational hepatitis $\mathrm{C}$ virus infection in Italian health care workers. American J Public Health 1995; 85 (9): 1272-1275. 